\title{
MODEL PEMBELAJARAN BOLA BASKET MELALUI MODIFIKASI SARANA DAN PRASARANA UNTUK MENINGKATKAN DENYUT NADI MAKSIMAL SISWA KELAS V SEKOLAH DASAR
}

\author{
${ }^{1}$ Resta Yolanda ${ }^{2}$ Asrini Nurhayu ${ }^{3}$ Jovana Renaldy Gumay
}

\author{
Correspondence: Pendidikan Olahraga Pascasarjana Universitas Negeri Jakarta, \\ Jakarta, Indonesia. \\ E-mail: restayolandaymr@gmail.com
}

\begin{abstract}
Abstrak
Penelitian ini bertujuan untuk menghasilkan model pembelajaran bola basket melalui modifikasi sarana prasarana untuk siswa kelas V Sekolah Dasar. Penelitian ini merupakan penelitian pengembangan yang mengacu pada model Borg and Gall yang dimodifikasi dalam tahapan: 1) pengumpulan informasi melaui observasi, 2) mengembangkan produk awal, 3) evaluasi/validasi ahli, 4) uji skala kecil, 5) revisi model produk, 6) uji skala besar dan revisi, kemudian 7) hasil akhir produk/ model. Berdasarkan data hasil penelitian melalui modifikasi sarana dan prasarana pembelajaran bola basket bahwa dengan model pembelajaran ini DN siswa kelas $V$ meningkat setelah penerapan, dari rata-rata 76.38 menjadi 127, 96 dengan total peningkatan $25 \%$. Hasil pengihitungan uji-t terhadap hasil penghitungan denyut nadi siswa sebelum dan sesudah mengikuti pembelajaran bola basket yang telah dimodifikasi menunjukkan $=0,000<0,05$ dan $t$ hitung $=19,05$. Kesimpulan bahwa pengembangan model pembelajaran bola basket melalui modifikasi sarana prasarana efektif meningkatkan DN siswa kelas V sekolah dasar dari model pembelajaran yang diterapkan sebelumnya. Sehingga model pembelajaran yang dikembangkan layak digunakan.
\end{abstract}

\section{Kata Kunci: Bola Basket, Prasarana, Denyut Nadi}

\section{Pendahuluan}

Permainan bola basket diciptakan oleh James A. Naismith atas anjuran Luther Halsey Gulick pada tahun 1891, Luther menganjurkan kepada James A. Naismith untuk menciptakan permainan baru yang dapat dimainkan di dalam gedung, mudah dimainkan, mudah dipelajari dan menarik. Pada mulanya James A. Naismith menggunakan keranjang sebagai sasarannya, oleh karena itu permainan ini disebut dengan basket ball, Muhajir (2006). Ternyata permainan ini sangat diterima dan mendapat sambutan baik oleh masyarakat, sehingga permainan ini menyebar dan berkembang pesat diseluruh dunia sampai saat ini. Permainan bola basket merupakan salah satu cabang olahraga beregu yang dimainkan oleh dua regu dimana masing-masing regu terdiri dari lima orang pemain yang bertujuan untuk menciptakan angka sebanyak-banyaknya.

Permainan bola basket termasuk permainan yang kompleks gerakannya, artinya gerakan terdiri dari gabungan unsur-unsur yang terkoordinasi secara rapi sehingga mampu memainkan bola dengan baik, Purwadi (2005). Sejalan dengan perkembangan zaman, olahraga ini telah banyak dimodifikasi, contohnya adalah three on three basketball dan streetball. Walaupun demikian, olahraga ini tetap saja olahraga beregu, karena permainan bola basket adalah olahraga beregu, maka 
harus ada kerjasama yang baik antara individu yang satu dengan individu lainnya dalam regu tersebut. Tetapi kerjasama saja tidak cukup untuk membuat suatu regu keluar sebagai pemenang, untuk itu setiap individu haruslah memiliki teknik bermain yang baik, salah satu contoh dari teknik tersebut adalah shooting atau menembak. Keberhasilan suatu regu dalam permainan bola basket selalu ditentukan oleh keberhasilan dalam menembak, dari penjelasan tersebut kita dapat menarik kesimpulan bahwa shooting merupakan teknik terpenting dalam suatu permainan bola basket, seperti yang dikemukakan oleh Wissel, (1996), "Shooting (menembak) adalah keahlian yang sangat penting di dalam olahraga basket, teknik dasar seperti operan, dribbling, bertahan dan rebound mungkin mengantar seorang pemain memperoleh peluang besar membuat skor, tapi tetap saja pemain tersebut harus mampu melakukan tembakan.

Ruang lingkup pendidikan jasmani yang ditawarkan di sekolah dasar semestinya dikembangkan berdasarkan kebutuhan anak-anak, serta memperhatikan beberapa pertimbangan diantaranya: (1) dasar-dasar pengembangan program, (2) pola pertumbuhan dan perkembangan anak, (3) dorongan dasar anak-anak, dan (4) karakteristik serta minat anak. Materi basket yang diberikan bagi anak-anak atau siswa Sekolah Dasar seharusnya diberikan dalam bentuk permainan yang di modifikasi.

Modifikasi sarana prasarana olahraga dalam Pendidikan Jasmani sangat diperlukan khususnya bagi anak-anak, hal ini dikarenakan anak-anak secara fisik dan emosional belum matang, karena masih dalam perkembangan. Oleh karena itu modifikasi model pembelajaran harus dilakukan sesuai dengan perkembangan dan kebutuhan anak, sebagai bagian dari perwujudan pelaksanaan kurikulum pembelajaran Penjaskes di Sekolah Dasar. Pembelajaran dapat berjalan efektif dan efisien dengan pendekatan strategi pembelajaran yang tepat. Model pembelajaran pendidikan jasmani tidak harus berpusat pada guru, tetapi pada siswa, pembelajaran harus disesuaikan dengan perkembangan anak, isi materi serta cara penyampaian disesuaikan sehingga menarik dan menyenangkan, agar sasaran pembelajaran mengembangkan keterampilan olahraga dan perkembangan pribadi anak seutuhnya dapat tercapai. Pendidikan jasmani mempunyai hubungan yang erat dengan belajar gerak, yang paling utama adalah untuk meningkatkan kondisi jantung, paru-paru, otot dan sistem organ tubuh lainnya.

Menurut Hamzah dan Nurdin, (2011) suasana yang mestinya tercipta dalam proses pembelajaran adalah bagaimana siswa yang benar-benar aktif dalam belajar, keberhasilan satu mata pelajaran dapat dilihat dari keaktifan siswa. Untuk mengetahui partisipasi siswa yang aktif mengikuti pembelajaran adalah dengan mengetahui atau mengukur denyut nadi siswa dalam satu menit, denyut nadi normal seseorang adalah 70 - 80 kali permenit, tetapi pada orang yang rutin melakukan olahraga denyut nadi normal hanya dapat mencapai 50 - 60 kali permenit. Siswa yang aktif akan memiliki peningkatan denyut nadi, dari jumlah denyut nadi yang diukur sebelum mengikuti aktifitas pembelajaran. Dalam hal ini untuk meningkatkan denyut nadi diperlukan model pembelajaran yang bisa meningkatkan gerak aktif siswa dalam bentuk modifikasi sarana prasarana 
permainan, dan salah satu model pembelajaran yang bisa meningkatkan gerak aktif siswa dalam bentuk modifikasi sarana prasarana pembelajaran bola basket.

Dalam permainan bola basket dibutuhkan untuk malakukan gerakangerakan tubuh/fisik yang bertenaga juga terpenuhi dengan bermain bola basket. Berlari cepat, berhenti dengan tiba-tiba, melempar, menangkap, melompat dan mendarat, dalam keseimbangan tubuh yang baik merupakan keterampilan yang paling banyak dilakukan dalam bermain bola basket. Daya tahan kerja jantung yang baik, yang diperoleh melalui partisipasi aktif di dalam permainan bola basket, disamping tentunya perolehan kekuatan otot-otot dan kemampuan koordinasi gerak tubuh yang sempurna.

Pada bulan Maret 2014, penulis telah melakukan observasi dan melakukan penelitian pendahuluan di Sekolah Dasar Negeri 117 Palembang. Untuk lebih jelasnya, berikut ini disajikan rata-rata hasil penghitungan denyut nadi siswa sebelum mengikuti pembelajaran dan sesudah pembelajaran bola basket dari Sekolah Dasar menurut hasil observasi dan hasil penelitian pendahuluan yaitu dari 40 siswa kelas $\mathrm{V}$ sebelum melakukan pembelajaran rata-rata denyut nadi 63 denyut permenit dengan persentase $30 \%$ dan sesudah pembelajaran 93 denyut permenit dengan persentase $44 \%$.

Berdasarkan hasil penghitungan denyut nadi anak ketika pembelajaran permainan bola basket, masih dijumpai siswa yang tidak mengalami peningkatan denyut nadi bahkan ada siswa yang mengalami penurunan denyut nadi (denyut nadi setelah mengikuti pembelajaran lebih sedikit dari pada jumlah denyut nadi sebelum mengikuti pembelajaran). Menurut Soekarman, (1989) menyatakan bahwa takaran atau intensitas latihan untuk kebugaran adalah 60\%-90\% dari denyut nadi maksimal. Denyut nadi itu dipengaruhi oleh umur maka denyut nadi maksimal diperoleh dari: 220 dikurangi umur.

Disimpulkan dari rata-rata hasil penghitungan denyut nadi siswa sebelum dan sesudah mengikuti pembelajaran bola basket, bahwa: untuk siswa kelas V dari Sekolah Dasar tersebut, ketika dalam mengikuti pembelajaran bola basket hanya mampu mengalami kenaikan denyut nadi sebesar $41 \%$ dari denyut nadi maksimal. Hasil rata-rata kenaikan denyut nadi ketika mengikuti pembelajaran bola basket masih jauh dari rentangan intensitas latihan yang disarankan. Oleh karena itu dapat disimpulkan bahwa pembelajaran bola basket yang diberikan oleh guru kurang efektif dan kurang menumbuh kembangkan peserta didik untuk aktif bergerak.

Berdasarkan uraian di atas, sangat diperlukan upaya yang nyata untuk membuat siswa dalam mengikuti pembelajaran permainan bola basket khususnya di Sekolah Dasar. Agar peserta didik merasa senang, tidak bosan, membuat peserta didik menjadi aktif bergerak untuk melakukan bentuk-bentuk latihan ketangkasan sesuai dengan teknik dasar yang ada pada pembelajaran bola basket sehingga dapat meningkatkan keterampilan serta kebugaran jasmani peserta didik, dengan meningkatnya keterampilan serta kebugaran jasmani peserta didik maka akan meningkatkan denyut nadi peserta didik tersebut. Untuk mengatasi semua itu, maka perlu adanya modifikasi sarana prasarana model pembelajaran materi bola basket yang sesuai dengan kebutuhan peserta didik di Sekolah Dasar.

PJKR_

http://jurnal.unimed.ac.id/2012/index.php/jpehr/index 
Permainan bola basket merupakan salah satu materi yang terdapat dalam kurikulum mata pelajaran penjasorkes di Sekolah Dasar. Menurut UU No 20 Tahun 2003 Pasal 1 ayat 20: "Bahwa pembelajaran adalah proses interaksi peserta didik dengan pendidik dan sumber belajar pada suatu lingkungan belajar". Dalam pembelajaran bola basket khususnya di Sekolah Dasar harus disesuaikan dengan pertumbuhan dan perkembangan peserta didik.

Proses pembelajaran yang dilaksankan harus dapat mengupayakan siswa agar bisa secara maksimal dan aktif selama mengikuti pembelajaran. Salah satu upaya yang dapat dilakukan agar bisa memaksimalkan belajar adalah dengan mengorganisir permainan. Menurut Yoyo Bahagia, (2000) menyatakan ada tiga pertimbangan yang dilakukan oleh seorang guru dalam mengorganisir permainan agar siswa belajar secara maksimal diantaranya: (1) Organisasi harus berhubungan dengan permainan yang sebenarnya, (2) Formasi pembelajaran merupakan formasi yang paling baik untuk memaksimalkan siswa dalam belajaranya. (3) Kemajuan belajar dapat digambarkan melalui perubahan situasi permainan yang stasis kedinamis (permainan yang sebenarnya).

Untuk dapat bermain bola basket dengan baik, sangat perlu mempelajari teknik-teknik dasar bermain bola basket. Pada dasarnya ada beberapa teknik dasar bola basket, yaitu: (1) footwork (gerakan kaki), (2) shooting (menembak), (3) passing (operan), dan (4) dribbling bola. Olahraga bola basket juga memiliki karakter sosial tertentu dengan corak permainan yang banyak mengandung unsur "Pura-pura, menipu, dan muslihat". Ini dapat terlihat dari tindakan para pemain yang sarat dengan usaha mengelabui lawanya dengan berbagai gerak tipuan atau gerak pura-pura yang dilakukan dengan menggunakan hampir setiap bagian tubuhnya. Contohnya, tipuan untuk mengecoh lawan yang dilakukan dengan menggerakan mata, kepala, bahu, kedua tangan dan lengan, pinggang, kedua kaki dan tungkai, gerakan pura-pura mendrible, menembak, dan mengoper.

Pembelajaran adalah pemberdayaan potensi peserta didik menjadi kompetensi. Kegiatan pemberdayaan ini tidak dapat berhasil tanpa ada orang yang membantu. Menurut, Dimyati dan Mudjiono (2011) pembelajaran adalah kegiatan guru secara terporgram dalam desain instruksional, untuk membuat belajar secara aktif, yang menekankan pada penyediaan sumber belajar.

Metode pembelajaran merupakan cara melakukan atau menyajikan, menguraikan, dan memberi latihan isi pelajaran kepada siswa untuk mencapai tujuan tertentu. Metode pembelajaran yang diterapkan guru memungkinkan siswa untuk belajar proses, bukan hanya belajar produk. Belajar produk pada umumnya hanya menekankan pada segi kognitif. Sedangkan belajar proses dapat memungkinkan tercapainya tujuan belajar baik segi kognitif, afektif, maupun psikimotor.

Modifikasi berasal dari kata modifying berarti pengubahan atau perubahan, Bambang (1999). Modifikasi merupakan salah satu usaha yang dapat dilakukan oleh para guru agar pembelajaran mencerminkan developmentally appropriate practice (DAP). Oleh karena itu, DAP temasuk didalamnya "body sacling" atau ukuran tubuh siswa, yang harus selalu menjadi prinsip utama dalam memodifikasi pembalajaran penjaskes 
Menurut Ngasmain dan Soepartono dikutip oleh, Husdarta (2009) Alasan utama perlunya modifikasi adalah: (1) anak bukanlah orang dewasa dalam bentuk kecil, kematangan fisik dan mental anak belum selengkap orang dewasa, (2) pendekatan pembelajaran pendidikan jasmani selama ini kurang efektif, hanya bersifat lateral dan monoton, dan (3) fasilitas pembelajaran pendidikan jasmani yang sekarang, hampir semuanya didesain untuk orang dewasa. Modifikasi permaianan olahraga dapat dilakukan dengan melakukan pengurangan terhadap struktur permainan. Struktur-strukur tersebut menurut, Husdarta (2009) diantaranya: (a) Ukuran, berat atau bentuk peralatan yang digunakan, (b) Lapangan permainan, (c) Waktu bermain atau lamanya permainan, (d) Peraturan permainan (e) Jumlah pemain.

Permainan bola basket mini merupakan hasil modifikasi dari permainan bola basket sesungguhnya supaya anak-anak dapat tetap bisa bermain bola basket dengan kebutuhan anak baik laki-laki dan perempuan. Dalam permainan basket mini pada dasarnya adalah pendidikan karakter dan bersifat menyenangkan, pendidikan basket usia dini merupakan wadah untuk menanamkan fundamental permainan basket yang benar. Pada prinsipnya basket mini itu bermain, tidak melelahkan, semua bermain, peraturan sederhana, mengedepankan etika, fairplay, serta menyengkan.

\section{Metode}

Metode penelitian ini adalah penelitian model pengembangan yang merupakan jenis penelitian yang penggunaannya digunakan dalam memecahkan persoalan praktis dalam bidang ilmu sosial, ilmu alam, teknik, dunia pendidikan dan latihan. Menurut, Borg dan Gall (2011) yang di kutip oleh, Emzir (2011), lebih lanjut menurut, Sugiono (2009).

Prosedur penelitian pengembangan yang sudah dimodifikasi menurut Borg dan Gall, Departemen Pendidikan Nasional (2008) melibatkan lima langkah, sebagai berikut (1) Analisis produk yang akan dikembangkan, (2) Mengembangkan produk awal model pengembangan latihan fisik permainan bola basket, (3) Melakukan validasi ahli, (4) Melakukan uji coba lapangan, (5) Revisi produk. Sedangkan rancangan model dalam penelitian ini sebagai berikut:

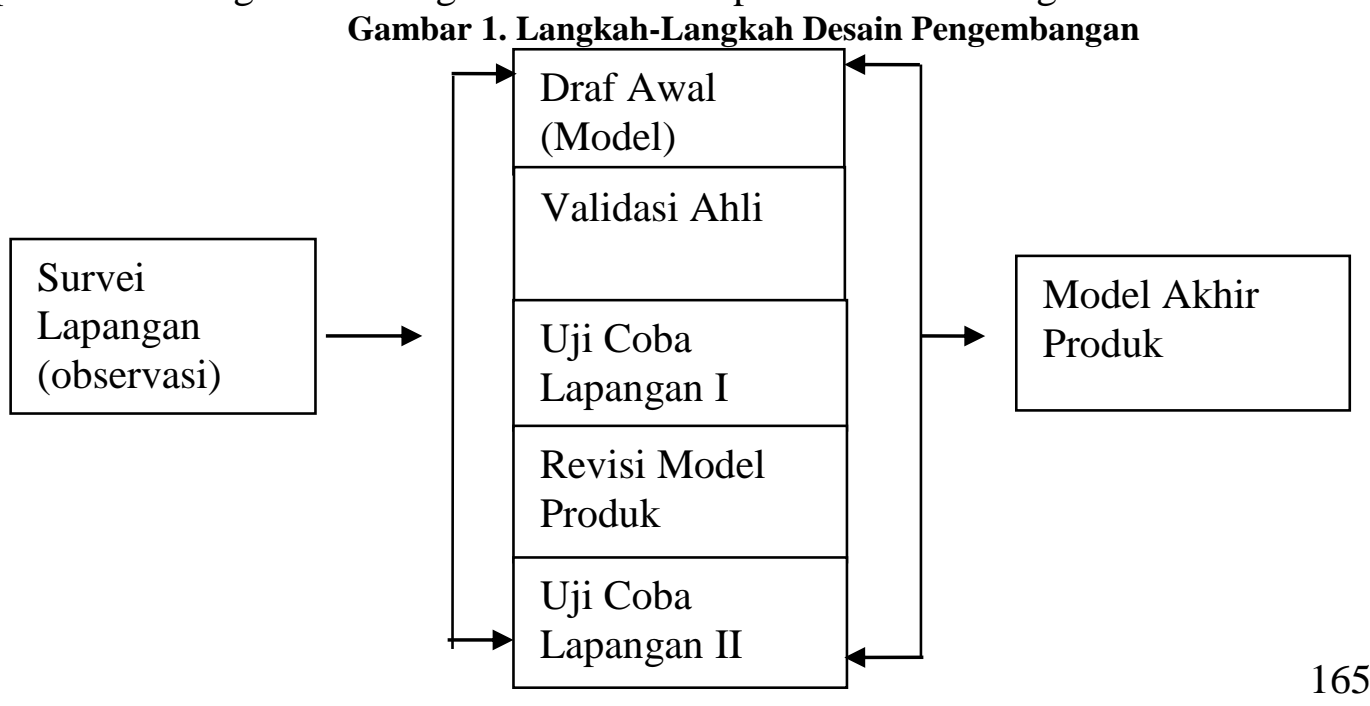

PJKR_

http://jurnal.unimed.ac.id/2012/index.php/jpehr/index 
Jenis data yang digunakan dalam penelitian ini adalah data kualitatif dan kuantitatif. Data kualitatif diperoleh dari hasil kritik, saran dari ahli penjaskes dan nara sumber secara wawancara, observasi dan penyebaran angket. Data kuantitatif diperoleh dari penghitungan deyut nadi siswa sebelum dan setelah mengikuti pembelajaran. Teknik pengumpulan data yang digunakan dalam pengembangan produk, menggunakan pedoman observasi dan kuesioner. Observasi dilakukan untuk mengumpulkan informasi tentang pelaksanakan proses pembelajaran penjaskes di Sekolah Dasar. Kuesioner digunakan untuk mendapatkan atau mendapat informasi dari para ahli maupun dari guru penjaskes untuk memberi masukan dan saran serta penilaian tentang kualitas model serta quesioner dari siswa sebagai pengguna produk.

Teknik analisis data yang digunakan adalah persentase untuk menganalisi dan penilaian subyek pengembangan dalam menilai tingkat kelayakan, kualitas, dan keterimaan suatu produk. Analisis yang digunakan untuk menguji data hasil pengukuran denyut nadi, dengan menggunakan uji-t agar untuk bisa mengetahui perbedaan atau pengaruhnya.

\section{Pembahasan}

Sekolah Dasar kelaas V atau usia 10-12 tahun. Peningkatan intensitas fisik dapat diketahui dari pengambilan data dari (1) denyut nadi, (2) angket dari siswa. Peningkatan denyut nadi sebagai instrumen peningkatan intensitas fisik, dipengaruhi oleh beberapa hal yang dapat mempengaruhi peningkatan tersebut, antara lain:

1. Model pembelajaran, konsep pembelajaran di buat dalam bentuk permainan yang dimodifikasi agar siswa selalu aktif.

2. Lapangan yang diperkecil, bola dengan ukuran kecil yang disesuaikan dengan anak sekolah dasar kelas $\mathrm{v}$ dan ring yang dimodifikasikan dengan kotak sampah akan memudahkan siswa untuk mengikuti pembelajaran.

3. Dengan adanya modifikasi bola basket, siswa selalu aktif bergerak dan mampu meningkatkan denyut nadi.

Penggunaan produk model pembelajaran bola basket bagi siswa, telah memberikan dampak atau pengaruh terhadap peningkatan denyut nadi siswa sebesar $25 \%$ dari denyut nadi maskimal siswa kelas $\mathrm{V}$, hasil penghitungan denyut nadi siswa sebelum pembelajaran dengan rata-rata denyut nadi 37,08 \% dan sesudah mengikuti pembelajaran bola basket mampu mengalami kenaikan sebesar $61,22 \%$ dari denyut nadi maksimal.

Hasil ini menunjukan kesesuaian dengan intensitas latihan yang disarankan yaitu 60\%-90\% dari denyut nadi maksimal, Djoko Pekik Irianto (2004). Hasil pengihitungan uji-t terhadap hasil penghitungan denyut nadi siswa sebelum mengikuti pembelajaran bola basket yang telah dimodifikasi menunjukkan $=0,000<0,05$ dan t-hitung $=19,05$. Sehingga terbukti bahwa pengembangan model pembelajaran meberikan dampak atau pengaruh terhadap kenaikan denyut nadi dan model tersebut bisa dikatakan memenuhi Efek Potensial. Berdasarkan data diatas maka model pembelajaran bola basket dapat 
meningkatkan asfek fisik siswa. Kevalidan ahli materi mengisi angket kevalidan model pembelajaran bola basket yang terdiri dari 12 butir soal penilaian. Total nilai angket dari ahli materi adalah sebesar 45 yang termasuk katagori baik, sedangkan dari ahli pengajar didapatkan total nilai angket sebesar 52 yang termasuk dalam katagori sangat baik. Total nilai angket kevalidan dari ahli materi dan ahli pengajar bisa dikatagorikan yang baik, karena nilai 45 dan 52 dalam rentang 41-50 yang termasuk katagori baik, dari penilaian ahli materi dan ahli pengajar maka dapat disimpulkan model sudah Valid dan dapat di uji cobakan ketahap selanjutnya.

Respon siswa terhadap hasil penghitungan kuesioner diperoleh data sebagai berikut: dari 10 menunjukkan butir soal no 10 memiliki persentasi nilai paling tinggi yaitu $100 \%$ yang termasuk kedalam katagori yang sangat kuat. Butir soal no 7, 8, 9, memiliki persentasi $95 \%$ yang termasuk dalam katagori sangat kuat. Butir soal no 3 memiliki persentasi $90 \%$ yang termasuk katagori sangat kuat. Butir soal no 1, 2 memiliki persentasi $85 \%$ yang termasuk katagori sangat kuat.

Berdasarkan hasil respon siswa setelah menggunakan model pembelajaran diatas, dapat disimpulkan bahwa sebagian besar siswa memiliki katagori sangat kuat dalam pembelajaran bola basket modifikasi. Hal ini didasarkan juga ats sedikitnya respon siswa yang masuk dalam katagori lemah pada semua aspek. Ini merupakan kemajuan dalam merespon pembelajaran bola basket modifikasi, mengingat sebagian besar siswa hanya menerima pembelajaran bola basket modifikasi pada waktu penelitian saja dengan waktu yang singkat, tetapi sudah memiliki respon yang kuat, dan responden yang dinyatakan kurang baik hanya sebagian kecil. Oleh karna itu, model pembelajaran bola basket modifikasi secara umum dapat memberikan pengaruh yang baik terhadap semua aspek sehingga bisa dikatakan bahwa model tersebut layak untuk digunakan ketahap selanjutnya dan sudah Praktis. Disamping itu, model pembelajaran bola basket modifikasi juga sangat efektif bagi siswa, karena dapat meningkatkan denyut nadi rata-rata sebesar 127,96 atau mampu mencapai intensitas latihan 60-90\% dari denyut nadi maksimal.

\section{Simpulan}

Dari hasil penelitian hipotesis dan pembahasan hasil penelitian maka dapat ditarik kesimpulan bahwa pengembangan model pembelajaran bola basket modifikasi dapat meningkatkan aspek fisik dan meningkatkan denyut nadi siswa kelas V Sekolah Dasar Negeri 117 Palembang.

\section{Rujukan}

Emzir, 2011. Metodelogi penelitian pendidikan kuantitatif dan kualitatif. Jakarta: PT Raja Grafindo Persada

Hamzah dan Nurdin, 2011. Model pembelajaran. Jakarta. PT. Grasindo

Husdarta, 2009. Manajemen Pendidikan Jasmani. Bandung: Alfabeta

Husdarta, 2010 Sejarah dan filsafat Olahraga. Bandung: Alfabeta

Ismaryati, 2011. Tes dan Pengukuran Olahraga. Surakarta: Unspres.

PJKR_

http://jurnal.unimed.ac.id/2012/index.php/jpehr/index 
Mudjiono, Dimyati, 2002. Belajar dan Pembelajaran. Jakarta: PT Adi Mahasatya Muhajir, 2006. Pendidikan Jasmani Olahraga dan Kesehatan. Jakarta: Erlangga

Purwadi, 2005. Pengaruh Latihan Jarak Bertahap dan Jarak Berpindah terhadap Hasil Tembakan Bebas Satu Tangan di Atas Kepala Pada Siswa Putra SMP $N 5$ Semarang. http://www.unnes.ac.id./library. diakses pada 5 Februari 2011

Sudjana, 2005. Metode statistika. Bandung: Tarsito

Sugiyono, 2005. Statistik Untuk Penelitian. Bandung: Alfabeta

Soekarman, 1989. Dasar Olahraga untuk Pembina Pelatih dan Atlet. Jakarta: CV Haji Masagung

Tim Puslitjaknov, 2008. Metode Penelitian Pengembangan. Jakarta: Departemen Pendidikan Nasional

Wissel, hall, 1996. Bola basket. Jakarta: PT. Raja Grafindo Persada

Yoyo bahagia, 2000. Prinsip-prinsip pengembangan dan modifikasi cabang olahraga Jakarta: Depdikbud, Dirjen Pendidikan Dasar dan Menengah, Bagian Proyek Penetaran Guru SLTP Setara D-III 